\title{
O CAPITAL JURÍDICO E O CICLO DA LITIGÂNCIA*
}

Ivo Teixeira Gico Jr.

THE LEGAL CAPITAL AND THE LITIGATION CYCLE

\section{RESUMO}

ESTE ARTIGO EXPLORA A POSSIBILIDADE DE INTERPRETAÇÃO DO DIREITO COMO UM BEM DE CAPITAL E AS IMPLICAÇÕES DESSA INTERPRETAÇÃO PARA A COMPREENSÄO DO COMPORTAMENTO AGREGADO DA LITIGIOSIDADE BRASILEIRA. A TEORIA INDICA QUE PODE HAVER UMA RELAÇÃO DIRETA ENTRE O ESTOQUE REAL DE CAPITAL JURÍDICO EM UM DETERMINADO ORDENAMENTO E O COMPORTAMENTO AGREGADO DE LITIGANTES, POIS UMA OFERTA SUBÓTIMA DE SEGURANÇA JURÍDICA GERA INCENTIVOS PRIVADOS AO LITÍGIO. ESSA INTER-RELAÇÃO DEVE GERAR UM COMPORTAMENTO CÍCLICO DE LITIGÂNCIA, NÃO OBSERVADO NO BRASIL.

\section{PALAVRAS-CHAVE}

Judiciário; Segurança Jurídica; Capital Jurídico; Ciclo DA LITIGÂNCIA; BRASIL.

\begin{abstract}
THIS PAPER EXPLORES THE INTERPRETATION OF LAW AS CAPITAL GOOD AND ITS IMPLICATIONS REGARDING THE AGGREGATE BEHAVIOR OF BRAZILIAN LITIGATION. THE THEORY INDICATES THAT THERE MAY BE A DIRECT LINK BETWEEN THE REAL STOCK OF LEGAL CAPITAL WITHIN A LEGAL ORDER AND THE AGGREGATE BEHAVIOR OF LITIGANTS, SINCE A SUBOPTIMAL OFFER OF LEGAL CERTAINTY CREATES INCENTIVES TO LITIGATE. THIS INTERRELATIONSHIP IS SUPPOSED TO GENERATE A CYCLICAL LITIGATION, WHICH IS NOT OBSERVED IN BRAZIL.

KEYWORDS
\end{abstract}

JudicIARY; LEgAL CERTAINTY; LEgal CAPITAL; LITIGATION CYCLE, BRAZIL.

\section{INTRODUÇÃO}

Todas as sociedades modernas possuem um sistema jurídico que estabelece regras de convivência. Tais regras são restrições institucionais formais que restringem o conjunto de possibilidades de cada um de seus integrantes, sendo variável o grau de sucesso alcançado por cada civilização neste esforço. É lugar-comum a concepção de que, para alcançar o desenvolvimento sustentável, é necessário que uma dada sociedade desenvolva e mantenha um sistema jurídico que funcione bem e dê sustentação a um bom sistema de governança (DAM, 2006). Nesse sentido, no início dos anos 1990, várias agências internacionais, como as Nações Unidas (COURT, HYDEN; MEASE, 2003) e o Banco Mundial (MESSICK, 1999; WORLD BANK, 2001), começaram a 
investir recursos na reforma de sistemas legais e judiciários de diversos países, ainda que a importância do sistema jurídico para o desenvolvimento fosse reconhecida há muito tempo por pensadores como Max Weber (1999 [1920]), um jurista e economista de formação, e também pelos participantes do movimento Law and Development da década de 1960 (BURG, 1997).

Não obstante, considerando que instituições formais e informais (cfr. NORTH, 2007 [1990]) são - em larga medida - idiossincráticas a cada povo, no Brasil ainda há pouca discussão acerca de como tais instituições são criadas e quais são mais benéficas ou prejudiciais a esse empreendimento coletivo que é a busca pelo desenvolvimento. Do ponto de vista das instituições formais, há pouca pesquisa sobre como os agentes sociais se mobilizam para a criação de regras de direito (Rule of Law) e quais as estruturas de incentivos necessárias para que isso ocorra. Nesse contexto, o Judiciário cumpre um papel fundamental, pois o sistema legal é estruturado substancialmente sobre essa organização, e seu desempenho pode determinar, em última instância, quão bem funciona o sistema de governança da sociedade brasileira. Há evidências empíricas persuasivas de que sistemas judiciais bem estruturados contribuem para o crescimento econômico (SHERWOOD; SHEPHERD; SOUZA, 1994; PINHEIRO, 1996).

A questão é ainda mais relevante quando se reconhece que o Judiciário brasileiro está em crise há anos, passando pela CPI do Judiciário de 1999 até a recente disputa acerca da competência ou não do Conselho Nacional de Justiça - CNJ para investigar magistrados. Mas o principal aspecto do que informalmente se chama de a "Crise do Judiciário" é a sua morosidade endêmica e persistente em resolver demandas judiciais. Desde a década de 1970, o Ministro do Supremo Tribunal Federal e autor do atual Código de Processo Civil - CPC, Alfredo Buzaid, já apontava para este problema (1972, p. 144 e ss.), decorrente de um descompasso entre a oferta e a demanda de serviços públicos adjudicatórios que impossibilitava o cumprimento de prazos judiciais.

O objetivo do presente artigo é propor uma teoria do comportamento do Judiciário enquanto organização em um sistema jurídico romano-germânico como o nosso, e investigar como os agentes sociais interagem para estabelecer o nível ótimo de utilização dessa tecnologia jurídica. A compreensão da inter-relação entre a formação e a depreciação das regras jurídicas, aqui consideradas uma forma de bem de capital o capital jurídico - e seu papel definidor no ciclo da litigância, permitirá um novo entendimento de como a organização do próprio Judiciário pode contribuir para o comportamento da litigiosidade.

O texto está organizado da seguinte forma: após esta introdução, no item 1, apresentamos um rascunho de uma teoria juseconômica do Estado para demonstrar a função social do Judiciário e, em especial, sua capacidade de produzir regras jurídicas que limitem os espaços de atuação dos agentes públicos e privados, i.e., determinem 
comportamentos. No item 2, discutimos como a segurança jurídica (estabilidade, uniformidade e coerência do sistema de regras) pode ser compreendida como um bem de capital, e em seguida, no item 3, discutimos os mecanismos sociais de depreciação e reposição desse capital que dará origem ao ciclo da litigância; depois desse item, seguem, então, as conclusões.

\section{A Função social do Judiciário}

O problema fundamental do desenvolvimento econômico é criar um ambiente institucional, dentro das possibilidades tecnológicas e das dotações disponíveis, que fomente a cooperação, aqui entendida como a coordenação de atividades produtivas entre os agentes e trocas voluntárias. Essa abordagem possui um aspecto privado e outro público.

Do ponto de vista privado, os agentes precisam desenvolver regras que os permitam migrar do estado da natureza para a sociedade civil. No estado da natureza cada agente deve estabelecer continuamente a alocação dos recursos disponíveis entre atividades produtivas (e.g. caça, coleta, plantio) e atividades distributivas (e.g. doar, roubar, matar). A alocação ótima de recursos dependerá das características pessoais (e.g. força, agilidade, altura, saúde) e ambientais (e.g. fartura, família, presença de predadores) de cada agente.

No estado da natureza, recursos escassos devem, portanto, ser alocados entre a produção e predação (atividades distributivas involuntárias). Como as atividades predatórias e de defesa não produzem qualquer riqueza, isto é, são atividades meramente redistributivas, todos os recursos a elas alocados são desperdiçados do ponto de vista social, i.e., reduzem o bem-estar social.

Teoricamente, é possível que uma troca coercitiva gere bem-estar social líquido positivo, desde que o expropriador atribua mais utilidade ao bem que o expropriado. Todavia, se trocas coercitivas fossem permitidas, considerando que não é possível a comparação intersubjetiva de utilidade, mesmo aqueles que atribuem menor valor ao bem que seu detentor original teriam incentivos para falsear sua valorização dizendo que o valorizam mais, no intuito de adquiri-lo coercitivamente. Esse comportamento oportunista se repetiria, e ressurgiriam os incentivos para alocar recursos entre atividades predatórias e defensivas. Estaríamos de volta ao estado da natureza. Assim, é a limitação impositiva a trocas voluntárias (livres de ameaça e coerção) que garante que ambos os agentes estão se beneficiando da troca e, portanto, que o bem-estar social aumenta.

Em um cenário de trocas voluntárias, produtores e predadores poderiam melhorar sua situação se encontrassem uma forma crível de cooperar e alocassem os recursos antes destinados à predação e à proteção às atividades produtivas. Tal alocação geraria um excedente que poderia, então, ser compartilhado entre ambos os grupos de acordo com alguma regra distributiva. Obviamente, a distribuição do excedente cooperativo 
dependeria do poder de barganha de cada agente, mas independentemente da distribuição, essa cooperação seria Pareto-eficiente.

Esse estado de cooperação é o que se convencionou chamar de sociedade civil e pressupõe, necessariamente, a presença de regras impostas aos agentes por alguma organização. Nas sociedades modernas, a organização que elabora e impõe essas regras é chamada Estado. Não é necessário que essa organização seja democrática para gerar bem-estar social, basta que haja a conversão do estado da natureza para a sociedade civil. Uma abordagem da história humana compatível com essa breve descrição quase hobbesiana pode ser encontrada em Acemoglu e Robinson (2006) e em North, Wallis e Weingast (2009).

A essas regras de convivência que se diferenciam da moral e dos costumes e são impostas pelo Estado se convencionou chamar direito (instituição formal). O primeiro instrumento para criar um compromisso crível de cooperação e superar o estado de natureza foi o estabelecimento do direito de propriedade. Com o estabelecimento e reconhecimento desse direito, a cada agente é informado de forma clara e precisa o que a coletividade reconhece como lhe pertencendo - logo, sobre quais recursos pode exercer seu domínio.

A definição clara do direito de propriedade de cada indivíduo libera recursos das atividades de predação e proteção e gera excedentes. Para maximizar a utilidade do agente produtor, esses excedentes precisam ser trocados com outros agentes possuidores de excedentes de outros bens, função para a qual o direito de propriedade é condição necessária (para que não haja predação), mas não suficiente.

Em trocas instantâneas, em que cada lado apresenta simultaneamente o seu produto ao outro lado, basta o estabelecimento claro e preciso do direito de propriedade para que as trocas ocorram. Estaríamos no mundo do escambo. Todavia, à medida que as trocas se tornam mais sofisticadas, as contraprestações se tornam diferidas no tempo e o número de agentes envolvidos cresce; o espaço para comportamentos oportunistas também aumenta e surge uma crise de confiança recíproca que - no limite - impede a troca (ou a expansão do mercado livre, em um vocabulário smithiano). O escambo não é mais um mecanismo suficiente e adequado para gerar a confiança mútua necessária para a superação do problema de desconfiança recíproca.

Diversas estratégias foram utilizadas ao longo da história humana para tentar superar o problema da desconfiança recíproca (DIXIT, 2007), desde reputação, guildas e controles informais até a restrição das trocas feita a membros de uma mesma ordem religiosa ou a troca de reféns como arras (para alguns exemplos, ver GREIF, 2006). Todavia, essas tecnologias negociais possuem claras limitações, como a necessidade de mecanismos pessoais de retaliação (e.g. ficar com um parente em garantia) ou a presença de interações reiteradas (e.g. reputação). Em uma sociedade moderna, na qual as interações sociais em larga medida são anônimas e uma parte substancial delas depende da interação de agentes que não se conhecem e, provavelmente, nunca 
se conhecerão, tais mecanismos são precários e insuficientes para dar sustentação à ordem social tal como a conhecemos. Na presença de uma autoridade central imparcial com poder de imposição sobre os agentes negociadores (coerção), a utilização do direito contratual pode ser uma alternativa superior.

O direito contratual é uma tecnologia jurídica desenvolvida para permitir que agentes realizem promessas uns aos outros e impeçam que suas contrapartes desviemse das promessas feitas. A ideia básica é que se os agentes realizam trocas voluntárias, benéficas ex ante para ambos (na opinião deles mesmos), e se um terceiro desinteressado pode impor tais obrigações assumidas na presença de tentativas de burlar o contrato (comportamento oportunista), então a possibilidade de imposição do comportamento acordado superaria o problema da desconfiança recíproca, e as partes cooperariam ex ante (confiariam). O direito contratual, portanto, é um instrumento de coordenação de agentes que os impede de adotar comportamentos oportunistas ex post, gerando assim a confiança necessária para a realização de investimento e de trocas diferidas no tempo.

O problema é que uma organização tão forte a ponto de conseguir impedir que qualquer um usurpe a propriedade de outrem e de fazer cumprir obrigações voluntariamente assumidas também é capaz de expropriar e impor obrigações, razão pela qual são necessárias limitações ao próprio poder do Estado. Tais limitações permeiam todas as áreas do direito, mas estão especialmente presentes no direito constitucional (lei fundamental que organiza o Estado), administrativo (regras sobre como proceder perante o administrado), tributário (regras sobre como expropriar para financiar) e financeiro (regras sobre como gastar os recursos arrecadados).

Além de restrições jurídicas, a estratégia organizacional adotada pela maioria das nações para limitar o poder estatal foi dividi-lo em entes relativamente autônomos, que seriam menos poderosos que o todo, os quais se controlariam e se contraporiam uns aos outros. É o que se convencionou chamar de separação dos poderes. A forma como cada sociedade escolheu para realizar tal divisão varia de país para país, mas a divisão enquanto estratégia é quase universal, principalmente em democracias.

No Brasil, a Constituição Federal estabelece que a União é formada por Poderes independentes: "Art. $2^{\circ}$ São Poderes da União, independentes e harmônicos entre si, o Legislativo, o Executivo e o Judiciário.” Os detalhes de cada Poder estão previstos em seu Título IV - Da Organização dos Poderes, sendo instituído um Poder Legislativo, a quem compete precipuamente o poder de elaborar as leis (art. 44 e ss. da CF), um Poder Executivo, a quem compete precipuamente executar as leis e implementar as políticas públicas (art. 76 e ss. da CF) e um Poder Judiciário, a quem compete precipuamente aplicar as leis em casos de conflito (art. 92 e ss. da CF).

Em nosso sistema, as regras a serem aplicadas são (ou deveriam ser) elaboradas majoritariamente pelo Congresso Nacional, composto pela Câmara dos Deputados e pelo Senado (art. 44 da CF), cujos membros são representantes eleitos do povo. Já a 
execução dessas regras e das políticas públicas delas decorrentes fica preponderantemente a cargo do Presidente da República (art. 76 da CF), também eleito pelo povo (art. 77 da CF). Por fim, o Judiciário, a quem compete fazer valer as leis e a Constituição (art. $5^{\circ}$, inc. XXXV da CF), não é composto por representantes do povo, mas por bacharéis em direito concursados (art. 93, inc. I da CF) ou advogados e membros do Ministério Público, nomeados pelo Poder Executivo e aprovados pelo Senado Federal (art. 94, 101, § único e 104, § único da CF).

A explicação comumente oferecida para que os membros do Poder Judiciário não sejam políticos, mas burocratas, é que seu papel seria de aplicação independente das leis aprovadas pelo Poder Legislativo e pelo Executivo (veto) e, portanto, quanto mais distantes do jogo político e de suas naturais flutuações, melhor. Como a função preponderante do Judiciário é técnica, ou seja, aplicar a lei, não seria necessário e muito menos recomendável que seus integrantes tivessem interesses políticos nas causas que julgam. Os juseconomistas costumam chamar esse papel de fazer valer as regras (enforcement). O Judiciário tem, pois, um papel impositivo.

No intuito de estruturar uma organização o mais independente possível do jogo político, o constituinte originário não se limitou a estruturar um Judiciário formado por burocratas; ele também estabeleceu garantias para que fosse externa e internamente difícil exercer pressões políticas sobre seus membros, em especial:

(i) a vitaliciedade (art. 95, inc. I da CF): um magistrado não pode ser demitido pelos demais Poderes, mas apenas pelo próprio Poder Judiciário em decisão definitiva (transitada em julgado) e em casos muito restritos;

(ii) a inamovibilidade (art. 95, inc. II da CF): um magistrado não pode ser retirado de sua área de jurisdição, para que não se possa manipular o resultado dos julgamentos trocando-o por magistrado que seja favorável a uma determinada posição; e

(iii) a irredutibilidade de subsídios (art. 95, inc. III da CF): um magistrado não pode ter seu salário, chamado subsídio, reduzido por seus superiores ou pelos demais Poderes.

Além dessas garantias constitucionais, outras garantias estão previstas na Lei Orgânica da Magistratura Nacional (Lei Complementar n. 35 de 1979). Independentemente dos possíveis incentivos ao comportamento oportunista que tal estrutura de proteção possa gerar, a organização burocrática e a concessão de inúmeras garantias aos membros da magistratura têm como finalidade principal a formação de uma organização que possa desempenhar sua função impositiva (fazer valer as leis) de forma independente dos demais Poderes. 
Em termos juseconômicos, é possível se compreender a estrutura brasileira de separação de poderes como um mecanismo desenhado para que o Judiciário seja uma organização em que a riqueza e o poder de seus membros (utilidade) não dependam do resultado de seus julgamentos e, portanto, que os magistrados não tenham interesse pessoal em relação ao resultado das decisões que prolatam.

A ideia é que, como a utilidade do magistrado não depende do resultado do processo, em tese os magistrados se comportariam como agentes desinteressados na implementação e proteção de barganhas políticas realizadas pelos membros dos demais Poderes convertidas em leis, bem como garantiriam que o acordo originário sobre a estrutura do próprio Estado (Constituição) não fosse violado. A existência de um terceiro desinteressado que faça valer - no longo prazo - as barganhas políticas necessárias para acomodar os interesses de uma sociedade plural tem função semelhante para os grupos políticos e para os particulares: superar o problema da desconfiança recíproca. No primeiro caso, essas barganhas chamam-se leis, e no segundo, contratos.

No espírito de proteção da sociedade civil e de limitação de poder e controle mútuo, em caso de divergência de interesses entre agente (magistrado) e principal (Executivo e Legislativo), como os demais poderes podem alinhar o comportamento dos magistrados a seus interesses políticos? A resposta da teoria jurídica tradicional é simples: o magistrado é servo e não senhor da lei, ele deve se submeter ao seu comando quando agir. Por óbvio, se a teoria jurídica tradicional funcionasse, bastaria mudar a legislação, pois como a função do Judiciário - em tese - é apenas aplicar a lei, em alterando-se o parâmetro (lei) o comportamento dos magistrados em cada julgamento também deveria ser alterado (decisão).

Essa visão é comum no meio jurídico quando se diz que, em um Estado de Direito, como o que o Estado brasileiro se propõe a ser (art. $1^{\circ}$ da CF), o magistrado é servo e escravo da lei, e a sentença pronunciada seria fruto do silogismo desta com os fatos (subsunção). O magistrado se limitaria à aplicação e à interpretação da lei (vontade popular), independentemente de suas próprias convicções (vontade pessoal). Obviamente, essa proposição, ainda ensinada nos bancos das faculdades, não parece muito compatível com um modelo de um agente racional maximizador. Essa questão foi e tem sido debatida por inúmeros estudiosos; destacamos o alerta de Carl Schmitt (1996 [1982]), a modelagem pioneira de Cooter (1983) e de Posner (1993) e o recente estudo empírico realizado por Danziger, Levav e Avnaim-Pesso (2011), a demonstrar que juízes são influenciados por outras questões que não apenas a lei no momento de decidir. ${ }^{1}$

Nos termos da literatura de agente-principal, na estrutura de incentivos brasileira há propensão ao surgimento de problemas de comportamento oportunista por parte dos magistrados (agentes), pois, uma vez estabelecida a sua independência, nada garante que o Judiciário se aterá ao texto da lei em vez de simplesmente passar a elaborar regras que reflitam melhor as preferências pessoais de cada magistrado. 
Uma primeira resposta a esse problema de agência deveria ser a escolha pelos demais Poderes dos membros integrantes do Supremo Tribunal Federal - STF (art. 101, $\S$ único da $\mathrm{CF}$ ), responsável pela última palavra em questões constitucionais, e do Superior Tribunal de Justiça - STJ (art. 104, § único da CF), responsável pela última palavra em questões de legalidade federal. Essa pré-seleção deveria ser suficiente para alinhar tais interesses. No entanto, como os Ministros são praticamente intocáveis (vide garantias constitucionais), uma vez escolhidos, esse mecanismo de alinhamento ex ante (pré-seleção) é claramente falho ex post.

É o que parece indicar a pouca evidência empírica a respeito, como o estudo de Jaroletto e Mueller (2011), a decisão do STF ao julgar a ADI n. 4277 e a ADPF n. 132, na qual foi reconhecida a união estável para casais do mesmo sexo, a despeito da literalidade do art. 226, $\S 3^{\circ}$ da $\mathrm{CF}^{2}$ e do art. 1.723 do $\mathrm{CC}^{3}$ e outros casos, como o da demarcação de terras em Raposa Serra do Sol (Pet 3388), o da imposição de fidelidade partidária (ADI n. 3.999 e ADI n. 4086), o da proibição de nepotismo (Súmula Vinculante n. 13) e o do uso restrito de algemas (Súmula Vinculante n. 11). Ao que tudo indica, na ausência de outros mecanismos de controle, o ativismo judicial é um resultado previsível dessa estrutura de incentivos (o que não deixa de ser um exemplo de problema agente-principal).

Essa estrutura de incentivos gera efeitos indesejáveis, tanto do ponto de vista de alinhamento entre o Executivo, o Legislativo e o Judiciário, que chamaremos de alinhamento entre poderes, quanto do ponto de vista de alinhamento de incentivos dentro do próprio Judiciário, que dividimos em alinhamento horizontal (dentro de um mesmo nível na organização judiciária) e vertical (entre níveis diversos na organização).

Mas, deixando de lado, por ora, os problemas de incentivos gerados pela estrutura organizacional do Judiciário brasileiro, fato é que a criação de um Estado para dar suporte à sociedade civil e a limitação do poder estatal para proteger e manter essa mesma sociedade civil são os aspectos públicos do problema fundamental de busca de mecanismos para criação da cooperação entre os agentes, cerne do desafio de desenvolvimento de todas as nações.

O Judiciário desempenha um papel central dentro desse arcabouço institucional. Do ponto de vista privado, a ele compete proteger os direitos atribuídos a cada cidadão, inclusive o direito de propriedade, bem como as alocações de tais direitos realizadas pelo próprio agente na realização de contratos. Enquanto o primeiro papel evita o desperdício de recursos com atividades predatórias meramente redistributivas, o segundo, ao eliminar ou mitigar a possibilidade de comportamentos oportunistas, permite a superação do problema de desconfiança recíproca e viabiliza a realização de contratos complexos.

Além disso, do ponto de vista público, as barganhas políticas negociadas entre os vários grupos integrantes do Legislativo e do Executivo materializam-se na forma de 
legislação, que depois deve ser aplicada (enforced). É o Judiciário que - ao aplicá-la garante credibilidade aos acordos políticos consubstanciados em lei. Essa credibilidade permite a cooperação de longo prazo entre grupos e reduz conflitos, comportamentos oportunistas e o emprego da violência. Por outro lado, tal sistema só é autossustentável se o poder do próprio Estado for restringido, razão pela qual regras limitadoras devem ser impostas a todos os entes componentes do Estado - e compete precipuamente ao Judiciário impor (enforce) tais regras em casos de conflito. Podemos, então, ilustrar o papel central do Judiciário da seguinte forma:

\section{Figura 1 - A FUnÇÃo SOCIAL do Judiciário}

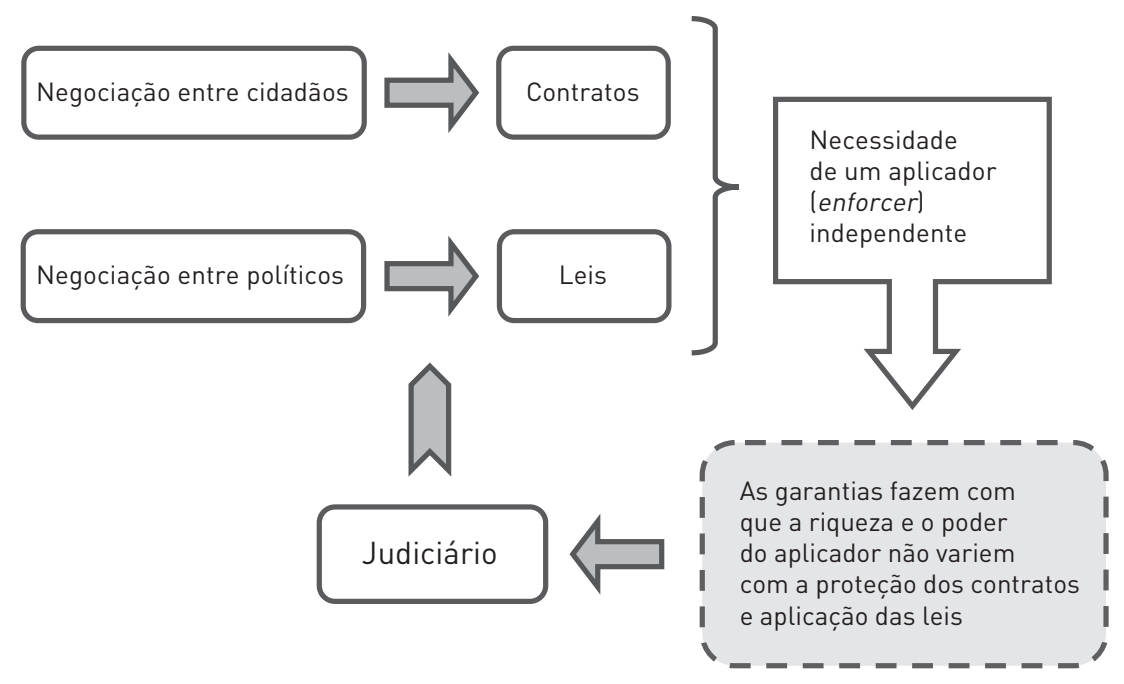

A função do Judiciário é, pois, atuar como um terceiro desinteressado capaz de impor às partes, ex post, as obrigações públicas (lei) e privadas (contrato) assumidas ex ante, fazendo com que o retorno esperado do comportamento desviante seja negativo. Como o comportamento desviante deixa de ser interessante para o agente social, as promessas realizadas por cidadãos e grupos políticos passam a ser críveis e supera-se, assim, o problema da desconfiança recíproca. O resultado é a cooperação.

Nesse sentido, podemos pensar no direito como um conjunto de regras fruto da experiência humana que vão se acumulando com o tempo, e à medida que a sociedade avança e cria novas situações, novas regras são criadas e antigas são reformuladas ou, simplesmente, abandonadas. Esse conjunto de regras informam ações e permitem a cooperação impessoal, viabilizando a estrutura da sociedade moderna. Mas como esse 
conjunto de regra se forma e funciona? É essa a pergunta que passamos a explorar no item seguinte.

\section{$2 \mathrm{O}$ DIREITO COMO CAPITAL JURÍDICO}

A primeira referência ao conjunto de regras jurídicas como um bem capital, com características de bem público, é o trabalho de Buchanan (2000 [1975]). Para Buchanan, os benefícios decorrentes da criação de uma regra jurídica, isto é, o retorno (yield) esperado não é auferido apenas em um período, como em um show de fogos de artifício, mas continuamente no futuro, como se viesse de um farol. O principal objetivo de se adotar leis seria restringir comportamentos em períodos futuros; restrições que, por sua vez, quando impostas a toda a coletividade, permitiriam o planejamento incorporador de previsões mais acuradas. O direito seria, portanto, um bem durável cuja utilidade se usufrui no decorrer do tempo (BUCHANAN, 2000 [1975], p. 99 e ss.).

No ano seguinte à publicação do trabalho de Buchanan, outros dois autores, Landes e Posner (1976), elaboraram um modelo juseconômico para a análise de precedentes legais derivado da teoria de formação de capital e investimento. Considerando a origem norte-americana dos autores, no modelo proposto foram consideradas apenas as regras jurídicas decorrentes de decisões judiciais com força vinculante, os chamados precedentes, tendo sido excluídas as regras jurídicas oriundas de leis, constituição e regulação. No presente item e subitens, adaptamos este modelo para que seja aplicável a todo e qualquer tipo de regra jurídica e, assim, possa ser aplicado à realidade de um sistema jurídico romano-germânico, como o brasileiro.

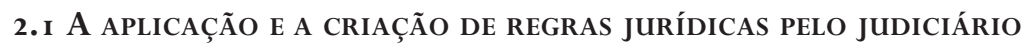

De início é importante chamar a atenção para o fato de não haver a figura dos precedentes no ordenamento jurídico brasileiro. O nosso sistema jurídico, de origem romano-germânica, é baseado em leis e códigos, isto é, em normas escritas. Mesmo as súmulas vinculantes, emitidas por Tribunais Superiores, funcionam mais como dispositivos de lei do que como precedentes propriamente ditos. Assim, quando as partes de uma disputa são incapazes de chegar a um acordo, elas levam sua questão (lide) para ser decidida por um magistrado. No curso do processo, para que possa tomar uma decisão sobre a lide, primeiro o magistrado deve decidir qual a legislação aplicável ao caso concreto. Essa legislação normalmente estabelece uma regra de decisão, que o magistrado usará para analisar o caso. Uma vez identificada (ou decidida) qual a regra aplicável, basta ao magistrado realizar um exercício de subsunção entre a regra jurídica escolhida e os fatos demonstrados no processo para decidir quem tem razão.

Apenas na inexistência de lei sobre a questão em juízo (lacuna jurídica) é que pode (ou deveria) um magistrado criar uma regra. Primeiro, consultando outras leis 
para casos parecidos (integração por analogia); depois, se não houver lei passível de analogia para caso semelhante, buscando costumes sociais que estabeleçam uma solução para a questão (integração por costume); e, por fim, se não houver nem um nem outro, o magistrado pode criar uma regra com base em um princípio jurídico, que nada mais é que um padrão jurídico extremamente amplo (integração principiológica). É o que determina a Lei de Introdução às Normas do Direito Brasileiro (Decreto-Lei n. 4.657, de 4/7/42): “Art. 4. Quando a lei for omissa, o juiz decidirá o caso de acordo com a analogia, os costumes e os princípios gerais de direito." Como se pode ver, no Brasil, até a forma de se aplicar as leis está prevista em lei.

Considerando-se que nesse sistema a regra aplicável ao caso concreto é aquela já prevista na legislação, o exercício de subsunção realizado pelo magistrado - em princípio - não seria relevante, pois tudo que o magistrado precisa saber para os próximos casos é a regra jurídica, que está contida na lei e não na decisão judicial anterior. É por isso que no Brasil se diz que uma decisão judicial vincula apenas as partes envolvidas no processo e não gera qualquer tipo de limitação ou vinculação para magistrados em outras decisões futuras. O que vincula é (ou seria) a regra estabelecida pela lei e não a interpretação da regra adotada por algum outro magistrado, ainda que de uma instância superior. Em resumo, no Brasil, a jurisprudência, conjunto de decisões anteriores, não tem força vinculante, mas apenas persuasiva.

Já em sistemas consuetudinários, como o norte-americano, uma parte substancial do direito e, em especial, o direito civil, é - em larga medida - o resultado do conjunto de decisões proferidas anteriormente por magistrados em casos iguais ou semelhantes. A pergunta acerca de qual a regra jurídica deve prevalecer em um dado caso é preponderantemente respondida não pela consulta a códigos e leis, mas mediante a consulta às formulações que algum magistrado criou para resolver casos anteriores cujos fatos são semelhantes aos do caso em análise. Como normalmente essas formulações são restritas ao caso concreto, é necessário um conjunto de decisões para definir um comando normativo genérico o bastante para ser aplicado a casos futuros. Essa formulação ou regra jurídica é chamada de precedente. ${ }^{4}$ Se houver um caso anterior semelhante, aplica-se o precedente (é o que se chama de stare decisis, está decidido). Do contrário, o magistrado cria uma regra nova para o caso em juízo, que poderá se tornar um precedente para casos futuros, se seguido.

Apesar dessa diferenciação tradicional entre o sistema romano-germânico e o sistema consuetudinário, sob uma abordagem mais realista da dinâmica processual no sistema brasileiro deve-se reconhecer que em muitos casos a legislação não estabelece uma regra clara a ser aplicada pelo magistrado. Essa falta de clareza pode decorrer da adoção de um padrão em vez de uma regra, como a interpretação de boa-fé dos contratos estabelecida pelo Código Civil ("Art. 113. Os negócios jurídicos devem ser interpretados conforme a boa-fé e os usos do lugar de sua celebração.”) ou a imposição de responsabilidade civil em caso de negligência (“Art. 186. Aquele que, por 
ação ou omissão voluntária, negligência ou imprudência, violar direito e causar dano a outrem, ainda que exclusivamente moral, comete ato ilícito.”). Tanto boa-fé quanto negligência são conceitos jurídicos indeterminados, cujos significados precisam ser construídos pelo magistrado no caso concreto. Por isso, os referidos dispositivos legais não constituem regras de comportamento, mas padrões de julgamento a serem construídos pelo Judiciário. Já a contagem dos juros de mora desde o momento da citação inicial (art. 405 / CC) ou a vedação de contratos cujo objeto seja herança de pessoas vivas (art. 426/CC) são regras jurídicas claras que demandam pouca ou nenhuma interpretação. Logo, são regras legislativas de comportamento, não padrões, que informam como as partes e o magistrado devem se comportar na presença de um litígio.

Por outro lado, na prática, mesmo regras jurídicas cujo conteúdo é perfeitamente inteligível podem ser alteradas pelo Judiciário à guisa de uma "interpretação" mais adequada. Por exemplo, o art. 649, inc. IV do CPC estabelece que são absolutamente impenhoráveis “os vencimentos, subsídios, soldos, salários, remunerações, proventos de aposentadoria, [...], os ganhos de trabalhador autônomo e os honorários de profissional liberal, observado o disposto no $\S 3^{\circ}$ deste artigo". Em outras palavras, de acordo com a lei, um magistrado não pode determinar a penhora do salário de um devedor para satisfazer o crédito de um credor. Para que não reste dúvida acerca da clareza da lei, o $\S 3^{\circ}$ a que se refere o inciso estabelecia uma exceção à regra de impenhorabilidade do salário, mas essa exceção foi vetada pelo Presidente Lula porque, nas palavras do próprio Presidente, ${ }^{5}$ é uma tradição brasileira proteger devedores:

$\$ 3^{\mathbf{0}} \mathrm{Na}$ hipótese do inciso IV do caput deste artigo, será considerado penhorável até $40 \%$ (quarenta por cento) do total recebido mensalmente acima de 20 (vinte) salários mínimos, calculados após efetuados os descontos de imposto de renda retido na fonte, contribuição previdenciária oficial e outros descontos compulsórios.

Não obstante, não é incomum encontrar decisões de Tribunais de Justiça permitindo a penhora legalmente proibida, desde que limitada a 30\% da remuneração. É, por exemplo, a decisão unânime da $1^{\text {a }}$ Turma Cível do TJDFT adotada no Acórdão n. 480791 de 9/2/11 (Rel. Des. Convocado Sandoval Gomes de Oliveira). Para uma demonstração cabal de que este exemplo de alteração jurisprudencial da regra jurídica prevista em lei não se trata de um caso isolado, basta consultar a página criada pelo próprio TJDFT com uma lista dos acórdãos favoráveis e acórdãos desfavoráveis à penhorabilidade de salários. ${ }^{6}$

É possível discutir se a modificação inserida pelo Judiciário é adequada, legítima (ou não), mas independentemente disso, em uma descrição positiva da realidade judicial (GICO JR., 2010, p. 19 e ss.) é necessário reconhecer que não se trata de uma questão de dúvida interpretativa, mas sim de alteração judicial da regra jurídica legislativa 
(interpretação contra legem). Note que a questão vem sendo decidida para um lado e para outro há anos (há acórdãos de 2006 a 2013 permitindo e proibindo), sem que o TJDFT adote uma posição única. Assim como nesse caso, há inúmeras outras questões cujas regras jurídicas aplicadas pelo Judiciário são diferentes das legalmente previstas, como a imposição pela Justiça do Trabalho de responsabilidade subsidiária do Estado em questões trabalhistas envolvendo terceirizados (cfr. antiga e atual redação da Súmula 331 do Tribunal Superior do Trabalho).

Se até a legislação, na prática, pode ser alterada pelo Judiciário, então, mesmo no sistema brasileiro, em que não há a figura do precedente, é possível se aplicar o modelo juseconômico de criação judicial de regras jurídicas, pois a regra de facto não necessariamente é a regra que está prevista em lei, mas sim o resultado da aplicação (ou não) dessa regra pelo próprio Judiciário. Note-se que o argumento não é que o Judiciário nunca segue a lei e, por isso, a existência de lei escrita pode ser ignorada para fins do modelo, ou seja, não se defende a equiparação do sistema brasileiro (romanogermânico) ao norte-americano (consuetudinário). O que argumentamos é que apesar de o nosso sistema ser preponderantemente baseado em leis e códigos, não raras vezes o Judiciário cria regras jurídicas a despeito do que prevê a legislação (mesmo na ausência de lacuna jurídica) e, portanto, a prática judicial - para o bem ou para o mal - nos permite considerar o direito que limita as ações dos agentes como o resultado das decisões judiciais para fins de análise positiva.

Obviamente, saber como funciona um sistema jurídico não vinculado pela lei e em que não há precedentes, isto é, onde nem mesmo as decisões de seus pares vinculam o magistrado na hora de decidir, é questão diversa. Fon e Parisi (2006) tentam responder a essa questão com um modelo dinâmico para descrever a evolução de decisões judiciais em sistemas civilistas, nos quais - como dito - a jurisprudência é meramente persuasiva. Na ausência do mecanismo de uniformização do stare decisis, em que basta uma única decisão para gerar um precedente, Fon e Parisi consideram que a jurisprudência é tanto mais persuasiva quanto mais consolidada for, sendo possível a existência de tendências e modismos. O mais interessante desse modelo é que um choque pode produzir insegurança e jurisprudência dividida que se perpetuam no tempo, em vez de se estabilizar em uma posição consolidada, ou seja, uma pequena perturbação pode levar à insegurança jurídica de longo prazo. Esse resultado é compatível com a discussão realizada anteriormente e reforça a ideia aqui defendida de que, em um sistema sem mecanismo de uniformização de jurisprudência, é possível e provável que eventuais variações de entendimentos judiciais não sejam uniformizadas e o sistema permaneça instável, gerando insegurança.

Explicado como o Judiciário brasileiro cria regras jurídicas por meio de interpretação da legislação, em casos de conceitos jurídicos indeterminados ou lacuna, ou pela simples alteração da literalidade da lei (interpretação contra legem), analisemos como essa dinâmica pode ser interpretada do ponto de vista juseconômico como um 
mecanismo de criação, depreciação e reposição de capital jurídico, a partir de uma abordagem da teoria capital-investimento.

\subsection{MODELANDO O DIREITO COMO UM BEM DE CAPITAL}

O capital jurídico de uma sociedade é o conjunto de regras jurídicas (originalmente legislativas ou não) que o Judiciário aplica para um certo tipo de caso em um dado momento. Pelo fato de o Judiciário aplicar tais regras quando surge um conflito, os agentes sociais podem realizar previsões acerca de como um magistrado resolveria determinado tipo de problema. Essa previsibilidade, que chamaremos segurança jurídica, permite aos agentes saberem e negociarem ex ante a quem fica alocado o risco de um determinado evento ou os custos de um determinado sinistro. Além disso, caso o risco de um determinado evento ou os custos de um determinado sinistro não tenham sido expressamente previstos em um contrato, seja porque não há contrato (e.g. em um caso de responsabilidade civil extracontratual), seja porque as partes não anteviram o evento ou preferiram não regulá-lo (lacuna contratual), a previsibilidade da conduta do magistrado permite aos agentes que, na presença do evento conflituoso, emulem o resultado de um julgamento sem precisar recorrer ao Judiciário.

Assim, por exemplo, em um acidente de trânsito em que uma das partes bate na outra por trás, já sabendo que o Judiciário vai presumir sua culpa há uma maior probabilidade de o condutor que abalroou por trás concordar espontaneamente em indenizar o condutor do veículo da frente. Essa cooperação espontânea (autocomposição) alcança o mesmo resultado que seria alcançado por um julgamento (heterocomposição), sem que se incorra nos custos de adjudicação; logo, é mais eficiente.

O capital jurídico de uma sociedade é o fruto de suas experiências e valores no decorrer do tempo. Quanto maior o capital jurídico de uma sociedade, maior o número de situações em que os agentes podem antever o provável resultado de um determinado conflito, caso esse fosse levado ao Judiciário; assim, é mais fácil alocar riscos e custos ou celebrar um acordo extrajudicial. Essa segurança jurídica permite o planejamento de longo prazo, a melhor alocação de riscos, o desestímulo a determinados comportamentos oportunistas e, em última análise, a cooperação entre os agentes.

A segurança extraída do capital jurídico não é consumida em um único período; ela é usufruída continuamente enquanto aquelas regras forem aplicadas pelo Judiciário, razão pela qual o capital jurídico é um bem durável (BUCHANAN, 2000 [1975], p. 99 e ss.). Nessa linha, seguindo Landes e Posner (1976), podemos modelá-lo da seguinte forma. Seja $J_{t}^{i}$ o estoque de capital jurídico da sociedade em uma determinada área jurídica $i$ (a i-ésima área do direito) no período $t$. O estoque de capital jurídico é o conjunto de regras jurídicas previsivelmente aplicáveis a um caso concreto que foram se acumulando no decorrer do tempo em períodos anteriores $(t-1, t-2, t-3$, etc. $)$. A fim de formarem capital jurídico, essas regras devem ser necessariamente previsíveis, para que possam gerar segurança jurídica aos agentes e, assim, permitir os ganhos 
de emulação e previsão de uma sentença futura. Regras ambíguas ou de difícil aplicabilidade não formam capital jurídico. Além disso, ao contrário do modelo de Landes e Posner, a origem dessas regras não precisa ser necessariamente judicial, podendo ser legislativa, constitucional ou mesmo administrativa ou regulatória; basta que o resultado de sua aplicação seja previsível e a regra seja mantida pelo Judiciário (estável), caso venha a ser contestada judicialmente.

Assim, o estoque de capital jurídico em um período $t$ pode ser definido como (LANDES; POSNER, 1976, p. 262 e ss.):

$J_{t}^{i}=I_{t-1}^{i}+\left(1-\delta^{i}\right) J_{t-1}^{i}$

EQUAC̣ÃO 3-1

onde $I_{t-1}^{i} \geq 0$ é o investimento bruto em capital jurídico realizado no período anterior $t-1$ e $\delta^{i}$ é a taxa de depreciação do capital jurídico no intervalo $t-1$ a $t$. Para fins de simplificação, pode-se considerar $\delta^{i}$ constante.

Agora $J_{t}^{i}$ pode ser expresso como uma função dos investimentos e da depreciação ocorrida em todos os períodos anteriores. Substituindo $J_{t-1}^{i}, J_{t-2}^{i}$ etc., é possível reescrever a Equação 3-1 da seguinte forma:

$J_{t}^{i}=I_{t-1}^{i}+\left(1-\delta^{i}\right) I_{t-2}^{i}+\left(1-\delta^{i}\right)^{2} I_{t-3}^{i}+\ldots+\left(1-\delta^{i}\right)^{t-1} I_{0}^{i} \quad$ EQUACุÃO 3-2

onde $I_{0}^{i} \geq 0$ é o investimento bruto em capital jurídico realizado no período inicial 0 . A Equação 3-2 ilustra o argumento de que o investimento em qualquer período incrementa o capital jurídico nos períodos subsequentes, sendo que este incremento vai sendo consumido gradativamente a cada período na medida da taxa de depreciação $\delta$. Em outras palavras, o direito é o fruto da experiência acumulada do homem; parte dele também envelhece, e precisa ser renovada de tempos em tempos.

Mas como se explica a depreciação do capital jurídico que é um capital intelectual semelhante ao conteúdo de um livro ou uma patente? Uma regra jurídica não se deteriora ou é consumida no sentido físico, ela se deprecia no sentido econômico porque o valor social da informação que ela carrega pode declinar no decorrer do tempo de acordo com as mudanças das circunstâncias (LANDES; POSNER, 1976, p. 267 e ss.). Mudanças em condições econômicas ou sociais, na legislação, nos integrantes do tribunal competente ou em outros parâmetros jurídicos constituem um choque externo que pode reduzir o valor das regras jurídicas em apreço para fins de segurança jurídica e, portanto, a utilidade extraída do capital jurídico. 
A título de exemplo, considere o caso de casais homossexuais que desejavam compartilhar os frutos de uma união civil (e.g. direito à pensão, seguro-saúde, herança). Até o dia 5 de março de 2011, data do julgamento conjunto da ADI n. 4.277 e da ADPF n. 132 pelo STF, tendo em vista a interpretação dominante dos Tribunais no sentido de que o art. 226, $\S 3^{\circ}$ da CF e o art. 1.723 do CC vedavam a união estável entre pessoas do mesmo sexo, homossexuais que desejavam os efeitos jurídicos da união estável precisavam usar outros mecanismos mais custosos e menos eficazes, como a formação de empresas para aquisição de bens comuns, a criação de condomínios de imóveis etc., para obter - de forma imperfeita - os efeitos civis de uma união estável, tecnologia jurídica disponível aos heterossexuais. Independentemente de seu juízo de valor com relação à legitimidade ou adequação dessa vedação, para fins da análise proposta aqui o que importa é que a regra era clara e, portanto, os agentes sabiam quais direitos lhes eram atribuídos ou negados (o que economistas tradicionalmente chamariam de definição clara dos direitos de propriedade). Justamente por isso essa regra integrava o capital jurídico brasileiro no período até março de 2011.

Com a mudança de entendimento do STF, essa regra foi alterada e passou a ser possível a equiparação da união homoafetiva à entidade familiar, mas exatamente o que isso significava do ponto de vista jurídico não ficou claro. Por exemplo, o STF reconheceu a união estável, mas e o casamento? Há uma diferença jurídica com algumas implicações na vida civil entre união estável e casamento; não é uma diferença meramente nominal. Em junho do mesmo ano, a própria decisão do STF foi contestada por um juiz da $1^{\mathrm{a}}$ Vara da Fazenda Pública Municipal e Registros Públicos de Goiânia, Jerônymo Pedro Villas Boas, que determinou - de ofício - o cancelamento do contrato de união estável entre o jornalista Leorcino Mendes e o estudante Odílio Torres, que havia sido reconhecido pelo $4^{\circ}$ Registro Civil e Tabelionato de Notas de Goiânia, e proibiu que os cartórios de Goiás reconhecessem outros contratos de união estável (cfr. Procedimento Ex-Officio - art. 25, 4 do COJEG, TJGO e o Processo n. 3772527 da Corregedoria Geral de Justiça do Estado de Goiás). Independentemente da decisão desse magistrado, cartórios pelo Brasil afora ficaram na dúvida se poderiam ou não realizar casamentos entre pessoas do mesmo sexo. Várias decisões judiciais foram proferidas para autorizar ou mesmo comandar tal registro, mas essas decisões só têm eficácia sobre os cartórios na jurisdição de cada magistrado ou Tribunal. Em outras comarcas, magistrados reiteradamente bloqueiam o casamento homossexual.

Para se ter uma ideia da dificuldade da questão, em 25 de outubro de 2011, a Quarta Turma do STJ, por maioria, reconheceu no REsp n. 118.337-8 / RS o direito de casar requerido por duas mulheres gaúchas. O fundamento foi justamente a decisão anterior do STF. Não obstante, como essa decisão do STJ não é vinculante (lembre-se, não existe precedente no Brasil), outros casais homossexuais interessados em casar ainda estão à mercê do entendimento específico dos cartórios e dos Tribunais 
de cada região. No Rio de Janeiro, por exemplo, todos os pedidos são negados porque o juiz responsável na $1^{\text {a }}$ Vara de Registro Público do Rio entendia que há vedação legal e que a decisão do STF não alcança o casamento, mas apenas a união estável (cfr. MIRANDA, 2012). No Distrito Federal, um cartório aceita e o outro não. Como se pode ver, decorridos anos da mudança de posição do STF, não existe de facto uma única regra jurídica em vigor acerca da possibilidade ou não de casamento homossexual no Brasil.

A vedação anterior e suas implicações jurídicas foram construídas durante o tempo e geravam segurança jurídica, isto é, integravam o capital jurídico. Com a mudança da regra, esse capital se depreciou e o Judiciário passou a ter de reconstruir nos períodos seguintes as regras associadas a essa nova possibilidade. Nesse sentido, o valor informacional das regras anteriores se depreciou (as regras tornaram-se obsoletas), isto é, ele diminuiu e precisou ser reposto por meio de novos investimentos em decisões judiciais, que ainda estão em andamento. Note-se que, dada a natureza civilista de nosso sistema, essa depreciação poderia ser rapidamente reposta pelo investimento legislativo estabelecendo a regra jurídica para o casamento homossexual (permitindo-o ou proibindo-o novamente), que por ser obrigatória em todo território nacional (força cogente) tenderia a resolver a questão de forma unificada e rápida. Todavia, dada a natureza emocional, política e religiosa da questão, os custos de transação associados à negociação política desse tema tornam a realização do investimento jurídico proibitiva naquele momento.

De uma forma geral, a passagem do tempo tende a reduzir o valor informacional das regras jurídicas acumuladas, e essa redução representa a depreciação ou obsolescência do capital jurídico. Tal qual ativos materiais, é possível cogitar que jurisprudências ou institutos jurídicos inativos há muito tempo possam ser reativados para orientar casos novos sobre questões semelhantes, como a utilização do instituto milenar da servidão, ${ }^{7}$ que poderia ser usada para resolver casos de conflitos sobre construções que obstruam a vista de uma outra propriedade. A solução judicial: a criação da servidão visual. Essa possibilidade é semelhante a um maquinário que, desativado, por alguma razão passa a ser útil novamente e volta a ser usado, não necessariamente para a exata mesma finalidade.

Esclarecido o significado da depreciação ou da obsolescência do capital jurídico, retomemos a construção do modelo com a discussão do valor por ele criado. Seja $U_{t}^{i}$ a utilidade do fluxo de informações gerado pelo estoque de capital jurídico na i-ésima área do direito no período $t . U_{t}^{i}$ pode ser expressa em função de $J_{t}$ e do número $N_{t}$ de agentes que integram uma determinada comunidade e que, potencialmente, usufruem do valor informacional gerado por $J_{t}$ (e.g. consumidores, produtores, empresas, cidadãos, estados nacionais etc.). Logo, temos: 
sendo que aqui se presume que $\frac{\partial U_{t}}{\partial J t}>0$ e $\frac{\partial^{2} U_{t}}{\partial J t^{2}}<0$,

isto é, a utilidade marginal do estoque de capital jurídico em relação a $J_{t}$ é positiva (quanto mais capital, maior o valor total do fluxo de informação), mas sua taxa de retorno é decrescente. Os retornos decrescentes do aumento do capital jurídico traduzem a ideia de que cada nova regra jurídica traz uma nova informação, mas um número excessivo de regras começa a tornar cada vez mais difícil diferenciar uma regra da outra, reduzindo o valor informacional relacionado ao modo como uma determinada disputa será decidida.

Além disso, deixando de lado o sobrescrito i para fins de simplificação da notação, $U_{t}$ é crescente em $N_{t}$, isto é, como o consumo da informação gerada por uma regra jurídica não exclui o consumo da mesma informação por outra pessoa, quanto mais pessoas integram uma determinada comunidade que pode usufruir da segurança jurídica gerada pelo capital jurídico, maior o valor total de $U_{t}$.

Logo, $\frac{\partial U_{t}}{\partial N_{t}}>0$

Essa característica é o resultado direto do reconhecimento da natureza de bem público do direito, e que já havia sido aventada sem formalização matemática por Buchanan (2000[1975]).

A utilidade do fluxo de informações gerado pelo estoque de capital jurídico decorre da possibilidade de os agentes saberem ex ante quais comportamentos são permitidos e quais são proibidos pelo direito, e as sanções jurídicas associadas a cada violação, inclusive sua magnitude. Nesse sentido, o valor do capital jurídico está intimamente ligado à eficácia com que as regras jurídicas determinam comportamentos dos agentes. Uma regra jurídica meramente nominal (a famosa lei que não pegou) não constitui, portanto, capital jurídico, ou, se constitui, sua utilidade é nula ou, possivelmente, negativa.

$\mathrm{O}$ investimento em capital jurídico em um período $t-1$ é o conjunto de acórdãos, leis, decretos e regulações administrativas produzido no período. E aqui vale uma observação: usa-se a expressão acórdão e não decisão judicial para diferenciar entre decisões judiciais proferidas por um juiz singular de $1^{\mathrm{a}}$ instância (sentença) de uma decisão judicial colegiada proferida por órgão de $2^{a}$ instância (acórdão). Como na sistemática jurídica brasileira apenas as decisões dos tribunais são consideradas formadoras de jurisprudência, ${ }^{8}$ para fins da presente análise as fontes de investimento devem ser consideradas, do ponto de vista judicial, preponderantemente como sendo a produção de acórdãos, leis e regulações.

A elaboração de legislação e a produção de acórdãos consomem recursos escassos, como o tempo de congressistas, assessores, grupos políticos, magistrados, advogados, 
membros do Ministério Público, analistas judiciários, técnicos judiciários, testemunhas e partes, mais os recursos associados à construção e manutenção do Congresso Nacional, dos Tribunais de Justiça, do STJ, do STF, ou seja, de toda a infraestrutura que lhes dá suporte. Estes custos de investimento em capital jurídico no período $t$ podem ser representados da seguinte forma:

$C_{t}=C\left(I_{t}\right)$

EQUAC̦ÃO 3-4

onde se assume o custo marginal como positivo e não decrescente. O custo marginal de investimento positivo significa que quanto maior o investimento realizado, maior o custo associado $\left(C_{t}^{\prime}>0\right)$. Assim, por exemplo, supondo-se a ausência de capacidade ociosa, o aumento do número de acórdãos do STJ ou STF requereria a contratação de mais assessores, a construção de novas salas, a aquisição de mais equipamentos, o aumento do número de Ministros etc. Já o custo marginal de investimento não decrescente significa que ele pode até se manter estável, mas não diminuirá $\left(C_{t}^{\prime \prime} \geq 0\right)$.

Com base nesse modelo, podemos estabelecer a produção ótima de capital jurídico como o seguinte problema de maximização: seja $\pi$ a diferença entre a utilidade do fluxo de informação gerada pelo capital jurídico no período $t$ e o custo do investimento em cada período, sujeita à condição prevista na Equação 3-1, supondo-se $\delta$ constante e $I_{t}>0$, isto é, não é possível alienar capital jurídico. Assim, temos:

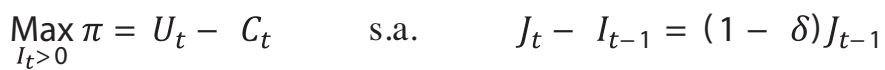

Resolvendo esse problema de maximização da maneira proposta por Landes e Posner (1976, p. 265), obtemos as seguintes $T$ condições de primeira ordem (de $T=0$ a $T-1)$ :

$$
\begin{aligned}
\frac{\partial \pi}{\partial I_{t}}= & R_{t+1} U_{t+1}^{\prime}+R_{t+2} U_{t+2}^{\prime}(1-\delta)+R_{t+3} U_{t+3}^{\prime}(1-\delta)^{2}+\ldots \\
& +R_{T} U_{T}^{\prime}(1-\delta)^{T-t-1}-R_{t} C_{t}^{\prime}=0
\end{aligned}
$$

onde $R_{t+j}$ é a utilidade no começo do período 0 do capital jurídico nos períodos $t+j$ $\left(R_{t+j}=1 /(1+r)^{t+j}\right.$, sendo a taxa de desconto por período $r$ constante $) ; U_{t+j}^{\prime}$ 
é o valor do produto marginal do capital jurídico em $t+j$ e $C_{t}^{\prime}$ é o custo marginal do investimento. Note que a condição de otimalidade prevista na Equação 3-6 constitui justamente a igualdade entre retorno marginal e custo marginal em equilíbrio decorrente de um investimento marginal no período $t$. Este equilíbrio é o que aconteceria em condições de concorrência perfeita; porém, na vida real, podem haver falhas de mercado - e há uma tendência a isso - que impedem o alcance do equilíbrio ótimo.

Enquanto Landes e Posner (1976, p. 265 e 266) avançam para discutir em que condições existe um equilíbrio de longo prazo e identificar a política de investimento ótima em capital jurídico, vamos analisar justamente a possibilidade de existência de um desequilíbrio de curto prazo, isto é, das consequências de um descasamento entre o estoque real e o estoque socialmente desejável de capital jurídico, assim como o investimento em sua formação e o impacto desse desequilíbrio sobre a estrutura de incentivos dos agentes em litígio.

\section{O CIClO DA LITIGÂNCIA}

Vamos investigar agora as consequências de um desequilíbrio de curto prazo entre o capital jurídico real em um determinado período $t$ e o nível ótimo de equilíbrio jurídico de longo prazo. Suponha que ocorra um choque que faça com que o estoque de capital jurídico fique abaixo do seu nível ótimo. Esse choque pode ser decorrente de uma mudança de posição no STF devido a uma nova composição, de uma mudança na legislação (como a introdução de um novo CPC), ou mesmo devido às mudanças inesperadas das condições socioeconômicas, como foi o caso da maxidesvalorização do real em 1999. Qualquer um desses choques pode imediatamente tornar obsoleta parte do estoque de capital jurídico existente. A presença de um estoque subótimo de capital jurídico gera insegurança jurídica. Essa insegurança faz com que aumente o número de casos perante o Judiciário, pois as partes considerarão mais difícil antever qual seria a regra jurídica aplicável ao caso concreto (aumento do hiato de expectativas) e, portanto, qual o valor esperado de um determinado acordo extrajudicial. O resultado será um incremento temporário de litígios (investimento privado) até que a discrepância entre o capital jurídico real e o ótimo desapareça.

Entretanto, essa simples explicação oculta dois aspectos fundamentais da função de produção de capital jurídico: (i) os insumos oferecidos pelas partes litigantes no Judiciário (e.g. contratação de advogado, tempo, peritos etc.); e (ii) os insumos oferecidos pelo magistrado que escreverá a decisão que poderá se tornar jurisprudência dominante no futuro para outros magistrados. ${ }^{9}$ Comecemos, então, pela questão levantada por Landes e Posner (1976, p. 271): considerando que os particulares se beneficiam apenas da resolução da controvérsia, mas não inteiramente da segurança 
jurídica decorrente da criação de jurisprudência (externalidade positiva), o que os induz a alocar recursos na produção de capital jurídico até alcançar o nível ótimo?

A resposta aparece de uma análise da estrutura de incentivos dos agentes privados. Por que as partes litigam? Normalmente os juristas respondem a essa pergunta nos livros de introdução ao processo civil afirmando que isso acontece porque um direito foi violado (e.g. IHERING, 2003 [1872], p. 41; COUTURE, 2008 [1949], p. 45 e ss.). Mas essa explicação não é satisfatória. Se um direito vale R\$10,00 para o ofendido e defendê-lo na justiça custará $\mathrm{R} \$ 50,00$, uma abordagem juseconômica nos informa que o agente racional maximizador não lutará por aquele direito na justiça, isto é, ele não litigará. Assim, um agente racional litigará apenas quando o retorno da litigância for não-negativo (cfr. LANDES, 1971; GOULD, 1973; POSNER, 1973; BEBCHUK, 1984; REINGANUM; WILDE, 1986). Note que aqui não estamos falando necessariamente de custo ou retorno monetário apenas. Uma pessoa profundamente ofendida pela conduta do réu pode litigar para receber apenas um pedido de desculpas ou uma indenização por danos morais de R \$ 100,00, ainda que isso lhe custe R \$500,00 em tempo, custas processuais, advogado etc. Basta que o autor extraia do resultado esperado da litigância (o reconhecimento de seu direito) mais utilidade do que lhe custa em desutilidade. Não obstante, se nesse caso o custo de litigar for R \$ 100 mil, provavelmente essa pessoa pensará duas vezes antes de acionar o ofensor. Por outro lado, e tão óbvio quanto, um agente racional em condições normais não gastará R \$ 100,00 em uma ação de cobrança de um cheque se o resultado esperado for coletar um crédito de R \$20,00. De um jeito ou de outro, o litigante racional litiga apenas quando o resultado esperado da demanda for não-negativo.

Uma pesquisa realizada recentemente por uma equipe de pesquisadores composta por juristas, economistas, sociólogos e administradores, predominantemente da $\mathrm{PUC} / \mathrm{RS}$ - e financiada pelo CNJ -, encontrou evidências empíricas que corroboram a conclusão de que as partes litigam não apenas porque tiveram um direito violado, mas também por causa (a) dos baixos custos de acesso e baixo risco; (b) das perspectivas de ganho; e (c) do uso instrumental do Judiciário (PUCRS, 2011).

Por outro lado, por que é que um caso vai parar no Judiciário quando as partes poderiam cooperar, realizar um acordo e dividir entre si o excedente gerado com a economia de todos os custos associados a uma ação judicial? Se um acordo é mais barato, por que litigar? A teoria juseconômica sugere que o litígio é o resultado da incapacidade das partes em alcançar um acordo, e essa incapacidade decorre de estimativas distintas de autor e réu sobre as reais chances de sucesso de cada um (hiato de expectativas) e, portanto, resulta de uma incapacidade em se concordar com o retorno esperado do litígio. Esse fenômeno é especialmente forte na presença de um viés de otimismo natural das pessoas que pode levar ao exagero da avaliação da probabilidade subjetiva de êxito e a aplicar um superdesconto às propostas de acordo oferecidas pela parte contrária (cfr., a título de exemplo, SILVA, 2011). 
Nesse sentido, a razão entre ações judiciais e acordos é uma função do estoque de capital jurídico (nível de incerteza jurídica) prevalecente em uma determinada área do direito, o que - por sua vez - leva a estimativas divergentes do resultado provável do processo pelas partes. Nos termos aqui desenvolvidos, a segurança jurídica é uma função do estoque de capital jurídico composto majoritariamente pela jurisprudência dominante. Para uma breve revisão da literatura sobre o aumento da taxa de litigância decorrente do aumento da incerteza devido à insegurança jurídica, vide Dari-Mattiacci e Deffains (2007, p. 11 e ss.), e para uma demonstração empírica dessa relação, vide Rezende e Zylbersztajn (2011). Neste estudo, os autores demonstram como a dispersão entre decisões no Tribunal de Justiça de Goiás sobre a validade de contratos de venda antecipada de soja elevou a insegurança jurídica, gerando aumento do número de litigância e, posteriormente, aumento de custos de transação na negociação de contratos futuros.

A ligação direta entre o nível de litigância e o estoque de capital jurídico garante que os particulares realizarão, ao menos em parte, o investimento necessário (alocação de recursos privados) para a formação de novo capital jurídico e o deslocamento do estoque de capital para obter o equilíbrio jurídico de longo prazo. Se esse incentivo é suficiente - do ponto de vista das partes litigantes - para alcançar esse equilíbrio é uma questão mais complexa. ${ }^{10}$

Considerando que o ganho privado decorrente de um acórdão é menor que o benefício social resultante, existe uma externalidade positiva na oferta de jurisprudência. Logo, provavelmente teremos um problema de suboferta de acórdãos. Como as partes litigantes não podem cobrar um preço pelo uso de jurisprudência formada a partir de seu caso, internalizando a externalidade (como faria, por exemplo, o autor de um livro ou o dono de uma patente), a presença de externalidades positivas parece justificar - ao menos em parte - a utilização de subsídios públicos à litigância, pelo menos em segunda instância. Esse argumento já foi usado por Shavell (1997).

Subsidiar a litigância é justamente o que o Brasil vem fazendo nos últimos anos, quando (a) criou os juizados especiais de pequenas causas, nos quais não é necessário um advogado e não há custas processuais; (b) criou a defensoria pública (advogados públicos pagos pelo contribuinte); (c) criou a assistência judiciária gratuita - AJG (possibilidade de não pagamento das custas processuais - mesmo na justiça comum -, nem dos honorários de sucumbência); (d) manteve o sistema de custas processuais abaixo do custo social de cada processo etc. Tudo isso significa que é o contribuinte quem arca com parte dos custos de cada processo, e não a parte litigante - o que claramente é um subsídio ao litígio e à parte da sociedade que litiga.

A insegurança decorrente da falta de capital jurídico aumenta os custos privados da celebração de um acordo extrajudicial (autocomposição), pois as partes têm dificuldades de estimar o resultado esperado, seja do ponto de vista da interpretação de uma determinada lei, seja do ponto de vista de ausência de uma jurisprudência clara 
e dominante em uma área envolvendo regras judiciais (e.g. conceitos jurídicos indeterminados). Esse incentivo à litigância provocará manifestações do Judiciário que, com o tempo, se converterão em jurisprudência que, se dominante, se transformará em capital jurídico. O resultado último é uma maior segurança jurídica sobre qual regra é aplicável àquele tipo de situação. Em outras palavras, o capital jurídico é um subproduto não intencional dos incentivos privados dos litigantes, uma externalidade positiva. Mais um exemplo de como as pessoas podem gerar bem-estar social motivadas pela busca de seus próprios interesses.

Por outro lado, vale lembrar que a insegurança jurídica como um todo nunca será eliminada, mas apenas mitigada, pois à medida que novas leis são promulgadas ou há alterações nas condições socioeconômicas que estruturavam as relações jurídicas, deprecia-se o capital jurídico existente, fazendo surgir novos surtos de litigiosidade que, por sua vez, dispararão respostas legislativas e/ ou a formação de nova jurisprudência que, se dominante, recomporá ao menos em parte o capital jurídico depreciado. O investimento em capital jurídico, tanto por meio de alteração legislativa quanto por mudança de jurisprudência, pode decorrer de uma série de pequenos problemas que geram mudanças incrementais ou até de um único problema, tão relevante que seja capaz de atrair suficientemente a atenção de determinados grupos políticos para que a mudança seja rápida e drástica, caso em que há uma recomposição quase instantânea do capital.

Com base na análise juseconômica exposta anteriormente, considerando apenas a estrutura de incentivos aos litigantes, podemos resumir a dinâmica decorrente de um desequilíbrio de curto prazo entre $J_{t}$, o capital jurídico em um determinado período $t$, e o nível ótimo de equilíbrio de longo prazo $J^{*}$ como um ciclo de expansão e de retração das taxas de litigância, que geram surtos e calmarias de processos de maneira cíclica e contínua. Essa flutuação esperada na atividade litigiosa é denominada ciclo da litigância, que pode ser resumido da seguinte forma: 


\section{Figura 2 - O CICLO DA LITIGÂNCIA}

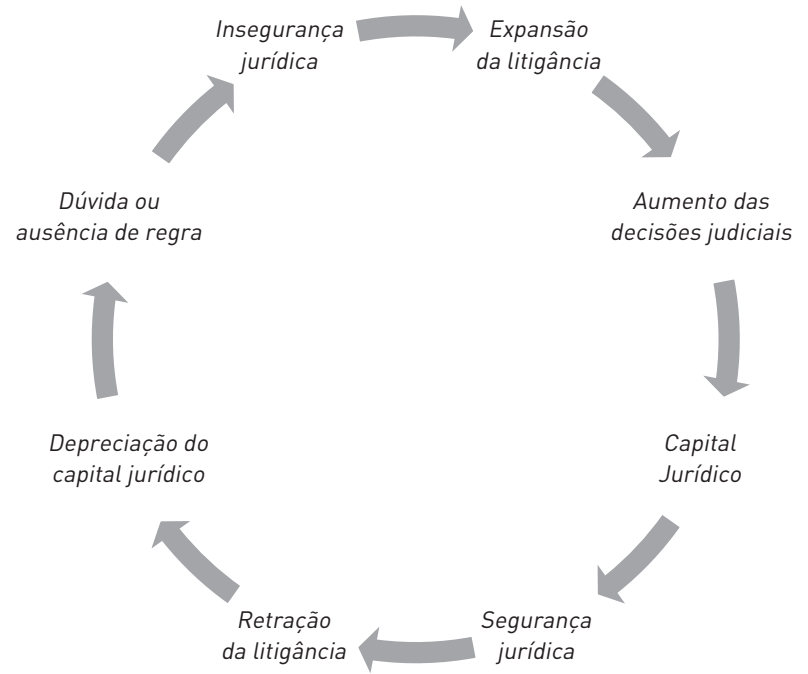

De uma perspectiva geral, podemos encarar o comportamento da atividade litigiosa na i-ésima área do direito não como um fenômeno isolado, mas como um conjunto de fenômenos. Nessa linha, o correto seria falar em ciclos de litigância, pois é um processo contínuo, mas não periódico, e cada ciclo pode variar em duração. Os ciclos de litigância seriam, então, um tipo de flutuação na atividade litigiosa; cada ciclo é composto por um período de expansão e um período de retração das taxas de litigância, ao que se seguiria uma nova fase de expansão. Note que há quem argumente que os sistemas jurídicos caminham inexoravelmente para uma maior insegurança jurídica (e.g. D’AMATO, 1983).

Considerando que a população mundial tem aumentado, em que pese as taxas decrescentes (UNITED NATIONS, 2004, p. 4); que a atividade migratória entre os países e regiões tem crescido, o que contribui para o multiculturalismo e para a variação de valores dentro de uma mesma sociedade; e que o número e a complexidade das interações sociais também tem aumentado, espera-se que, em média, o número total de litígios em uma determinada área do direito aumente, sendo os ciclos da litigância meras flutuações em torno dessa tendência subjacente, ou seja, um desvio transitório em relação a uma trajetória de longo prazo. O comportamento esperado dos ciclos de litigância pode ser descrito da seguinte forma: 


\section{Figura 3 - A TENDÊNCIA SECULAR DA LITIGÂNCIA}

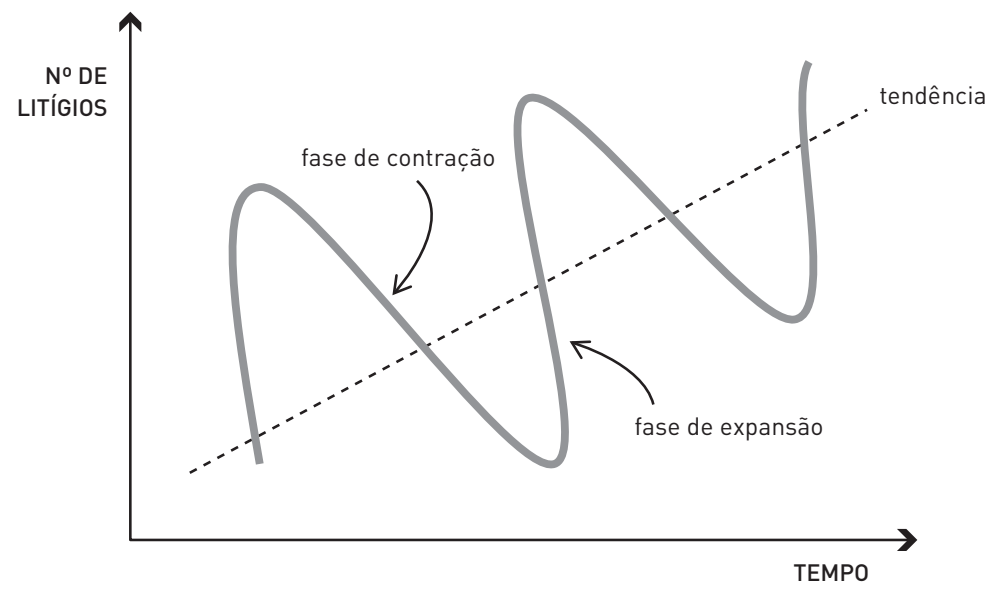

Pelo exposto, em um ordenamento jurídico balanceado é de se esperar que o nível de litigância seja algo cíclico, com expansões e retrações. A ausência desses ciclos ou o crescimento monótono ou quase-monótono da litigiosidade, como parece acontecer no caso brasileiro, indica uma patologia no ordenamento jurídico que deve ser identificada e tratada, pois, na linguagem juseconômica, não está havendo investimento suficiente em capital jurídico.

Nessa linha, considerando-se que a dinâmica do sistema judicial decorre da interação estratégica de seus agentes componentes, a compreensão plena do comportamento da litigiosidade brasileira requer uma investigação mais aprofundada da estrutura de incentivos, tanto das partes (autor e réu) quanto dos próprios magistrados (GICO JR., 2012). Enquanto não soubermos mais sobre a estrutura de incentivos de cada um desses grupos, não seremos capazes de verdadeiramente compreender o Judiciário e, portanto, seremos incapazes de formular políticas públicas adequadas.

\section{Conclusões}

O Judiciário tem uma função estruturante fundamental na construção da sociedade civil e no que se convencionou chamar Estado de Direito. Seu papel de garantidor das barganhas públicas (leis) e privadas (contratos) permite a cooperação de grupos em uma sociedade cada vez mais plural e complexa. Em última instância, não é possível conceber uma sociedade moderna sem a existência de um Judiciário eficaz.

No exercício de garantidor último das barganhas sociais, o Judiciário aplica e cria regras jurídicas que informam aos agentes como determinadas questões serão 
resolvidas caso surjam conflitos e os Tribunais venham a ser invocados para resolvê-los. Esse conjunto de regras, que podem ter origem legislativa ou judicial mas que, em última instância, dependem sempre da atividade adjudicatória, é o capital jurídico. Quanto maior o estoque de capital jurídico de uma sociedade, mais segurança sobre o resultado provável de conflitos - e, portanto, mais preparados estarão seus integrantes para elaborar planejamentos de longo prazo e cooperar. $\mathrm{O}$ acúmulo ótimo de capital jurídico seria, então, uma condição necessária para o desenvolvimento econômico.

Analisando a função de produção do capital jurídico apenas pelo lado de um de seus insumos, isto é, dos incentivos privados para litigar, conclui-se que a presença de um desequilíbrio de curto prazo entre o estoque real de capital jurídico e o ponto ótimo socialmente desejável gera insegurança jurídica. Essa insegurança aumenta os custos de transação das partes para a realização de acordos extrajudiciais (cooperação), aumentando assim a quantidade de litígios (investimento privado). Essa expansão da litigância, por sua vez, tem como subproduto a geração de jurisprudência que, se dominante, transformar-se-ia em capital jurídico e geraria segurança jurídica (capital), o que desincentivaria a litigância. Esse movimento esperado de expansão e retração da litigância para a reposição do capital jurídico depreciado constitui um comportamento cíclico que denominamos o ciclo da litigância.

No entanto, essa discussão ilustra apenas os incentivos para que as partes em um conflito invistam em litígio e, assim, produzam capital jurídico, mas nada foi dito sobre os incentivos para que os magistrados invistam na mesma produção. As partes estão submetidas a uma lógica de mercado, i. e., investirão na atividade litigiosa até que o seu benefício marginal se iguale ao seu custo marginal e - em períodos de insegurança (escassez de capital jurídico) - essa lógica se converte em incentivo para investir (litigar). O mesmo não vale para os magistrados. Lembre-se que o investimento privado em litígio se converte em capital jurídico apenas se os magistrados investirem na construção e manutenção da jurisprudência, o que não pode ser explicado somente com a presença de escassez de capital, pois os magistrados são burocratas que possuem o quase-monopólio da atividade adjudicatória, e a insegurança jurídica não necessariamente gera incentivos para que invistam em capital jurídico. Nessa linha, é necessário explicar o comportamento dos magistrados e como esse comportamento afeta a formação de capital jurídico, uma vez que as preferências de cada magistrado são tão variáveis quanto os interesses das partes litigantes. Mas essa resposta deixamos para pesquisas futuras.

: ARTIGO APROVAdo (02/12/2013) : RECEBIDO EM 28/06/2013 


\section{NOTAS}

* O autor agradece aos comentários e sugestões de Bernardo Pinheiro Machado Mueller, Maurício Soares Bulgarin, Giácomo Balbinoto Neto, Danielle Cristina Lanius, Nicolau Dino de Castro e Costa Neto e do parecerista anônimo. Este artigo foi parcialmente financiado com recursos da CAPES/CNPq.

1 Danziger, Levav e Avnaim-Pesso (2011) demonstraram que a chance de um magistrado judeu conceder liberdade condicional a um preso era diretamente proporcional ao tempo que o magistrado estava sem comer. Assim, logo após o almoço a chance de concessão era de cerca de $65 \%$, que ia caindo com o passar do tempo até quase zero. Após a pausa para o lanche, a probabilidade retornava abruptamente para os mesmos $65 \%$, para voltar a cair gradativamente.

2 “Art. 226. A família, base da sociedade, tem especial proteção do Estado.

$\S 1^{\circ}$ - O casamento é civil e gratuita a celebração.

$\S 2^{\circ}$ - O casamento religioso tem efeito civil, nos termos da lei.

$\S 3^{\circ}$ - Para efeito da proteção do Estado, é reconhecida a união estável entre o homem e a mulher como entidade familiar, devendo a lei facilitar sua conversão em casamento."

3 “Art. 1.723. É reconhecida como entidade familiar a união estável entre o homem e a mulher, configurada na convivência pública, contínua e duradoura e estabelecida com o objetivo de constituição de família.”

4 Um precedente não é a parte dispositiva do julgado, mas a menor regra lógica possível necessária para explicar o resultado do julgamento (holding), ainda que implícito. Por isso, normalmente se diz que é necessário um conjunto de decisões sobre temas muito próximos para se ter uma regra geral o suficiente para formar um precedente. Enfim, é uma regra de direito criada por um tribunal para um tipo de caso específico e reiteradamente utilizada como autoridade (fonte do direito) para decidir casos futuros semelhantes.

5 Mensagem $n^{\circ}$ 1.047, de 6/12/06: “[...] A proposta parece razoável porque é difícil defender que um rendimento líquido de vinte vezes o salário mínimo vigente no País seja considerado como integralmente de natureza alimentar. Contudo, pode ser contraposto que a tradição jurídica brasileira é no sentido da impenhorabilidade, absoluta e ilimitada, de remuneração. Dentro desse quadro, entendeu-se pela conveniência de opor veto ao dispositivo para que a questão volte a ser debatida pela comunidade jurídica e pela sociedade em geral. [...]” (destaque nosso).

6 Disponível em: <http://www.tjdft.jus.br/institucional/jurisprudencia/temas-em-debate/jurisprudenciacomparada/direito-processual-civil/penhora-2013-conta-salario>. Acesso em: 27 jan. 2014.

7 Servidão é uma restrição ao direito de propriedade de uma pessoa sobre um imóvel que valoriza outro imóvel. O instituto está previsto no CC: "Art. 1.378. A servidão proporciona utilidade para o prédio dominante, e grava o prédio serviente, que pertence a diverso dono, e constitui-se mediante declaração expressa dos proprietários, ou por testamento, e subseqüente [sic] registro no Cartório de Registro de Imóveis.” Note-se que nos termos do art. 1.379 do CC, é possível se adquirir esse direito real mesmo sem o consentimento da outra parte, se ela não se opuser por 10 anos.

8 Não por outro motivo, quando se pesquisa a jurisprudência no sítio de um Tribunal, normalmente as sentenças não estão disponíveis para consulta, apenas os acórdãos. A título de exemplo, cfr. <http://www.tjdft.jus.br/>.

9 Para uma discussão mais detalhada da função de produção do capital jurídico, ver o Capítulo 3 de (GICO JR., 2012).

10 Para uma discussão mais detalhada da estrutura de incentivos dos litigantes, vide o Capítulo 4 de (GICO JR., 2012). 


\section{REFERÊNCIAS BIBLIOGRÁFICAS}

ACEMOGLU, D.; ROBINSON, J. A. Economic Origins of Dictatorships and Democracy. New York, United States of America: Cambridge University, 2006.

BEBCHUK, L. A. Litigation and Settlement Under Imperfect Information. RAND Journal of Economics, 15 (3), 1984, pp. 404-415.

BUCHANAN, J. M. The Limits of Liberty: Between Anarchy and Leviathan (Vol. 7). Indianapolis: Liberty Fund, 2000 [1975].

BURG, E. M. Law and Development: A Review of the Literature \& a Critique of "Scholars in Self-Estrangement". The American Journal of Comparative Law, 25 (3), 1997, pp. 492-530.

BUZAID, A. Estudos de Direito. São Paulo, SP, Brasil: Saraiva, 1972.

COOTER, R. D. The Objectives of Private and Public Judges. Public Choice , 41 (1), 1983, pp. 107-132.

COURT, J.; HYDEN, G.; MEASE, K. The Judiciary and Governance in 16 Developing Countries. United Nations, United Nations University. United Nations, 2003.

COUTURE, E. Introdução ao Estudo do Processo Civil: discursos, ensaios e conferências. 2.ed. Belo Horizonte, MG, Brasil: Líder, 2008 [1949].

DAM, K. W. The Law-Growth Nexus: The Rule of Law And Economic Development. Brookings Institution Press, 2006. D’AMATO, A. Legal Uncertainty. California Law Review, 71, 1983, pp. 1-55.

DANZIGERA, S.; LEVAVB, J.; AVNAIM-PESSOA, L. Extraneous factors in judicial decisions. PNAS, 108 (17), 2011, pp. 6889-6892.

DARI-MATTIACCI, G.; DEFFAINS, B. Uncertainty of Law and the Legal Process. Journal of Institutional and Theoretical Economics, 163 (4), 2007, pp. 627-656. DIXIT, A. K. Lawlessness and Economics:Alternative Modes of Governance. Princeton: Princeton University Press, 2007.

FON, V.; PARISI, F. Judicial precedents in civil law systems: A dynamic analysis. International Review of Law and Economics, 26, 2006, pp. 519-535.

GICO JR., I. T. Metodologia e Epistemologia da Análise Econômica do Direito, Economic Analysis of Law Review, 1, 2010 , pp. 7-32.

I. T. A Tragédia do Judiciário: subinvestimento em capital jurídico e sobreutilização do Judiciário. Faculdade de Economia, Administração, Contabilidade e Ciência da Informação e Documentação - FACE, Departamento de Economia. Brasília: Universidade de Brasília - UnB, 2012.

GOULD, J. P. The Economics of Legal Conflicts. The Journal of Legal Studies, 2 (2), 1973, pp. 279-300.

GREIF, A. Institutions and the Path to the Modern Economy: lessons from medieval trade. Cambridge: Cambridge University Press, 2006.

IHERING, R. V. A Luta pelo Direito. São Paulo, SP, Brasil: Martin Claret, 2003 [1872].

JALORETTO, M. F.; MUELleR, B. P. O Procedimento de Escolha dos Ministros do Supremo Tribunal Federal uma análise empírica. Economic Analysis of Law Review, 2 (1), 2011, pp. 170-187.

LANDES, W. M. An Economic Analysis of the Courts. Journal of Law and Economics, 14 (1), 1971, pp. 61-107. LANDES, W. M.; POSNER, R. A. Legal Precedent: A Theoretical and Empirical Analysis. Journal of Law and Economics, 19 (2), 1976, pp. 249-307.

MESSICK, R. E. Judicial Reform and Economic Development: A Survey of the Issues. The World Bank Research Observer, 14 (1), 1999, pp. 117-136.

MIRANDA, A. Casamento gay: uma união ainda difícil no Rio. O Globo. Disponível em <http://oglobo.globo.com/ rio/casamento-gay-uma-uniao-ainda-dificil-no-rio-4976208>. Acesso em: 30 jan. 2014.

NORTH, D. C. Institutions, Institutional Change and Economic Performance. New York, NY, EUA: Cambridge University Press, 2007 [1990].

; WALLIS, J. J.; WEINGAST, B. R. Violence and Social Orders: A conceptual framwork for interpreting recorded human history. New York: Cambridge University Press, 2009.

PINHEIRO, A. C. Judicial System Performance and Economic Development. Rio de Janeiro, RJ, Brasil: BNDES, 1996. POSNER, R. A An Economic Approach to Legal Procedure and Judicial Administration. The Journal of Legal Studies, 2 (2), 1973, pp. 399-458.

.What Do Judges and Justices Maximize? (The Same Thing Everybody Else Does). Supreme Court Economic Review, 3, 1993, pp. 1-41.

PUCRS. Demandas Judiciais e Morosidade da Justiça Civil - Relatório Final Ajustado. Pontifícia Universidade Católica do Rio Grande do Sul, Faculdade de Filosofia e Ciências Humanas. Porto Alegre: Conselho Nacional de Justiça CNJ, 2011.

REINGANUM, J. F.; WILDE, L. L. Settlement, Litigation, and the Allocation of Litigation Costs. The RAND Journal of Economics, 17 (4), 1986, pp. 557-566. 
REZENDE, C. L.; ZYLBERSZTAJN, D. Quebras Contratuais e Dispresão de Sentenças. (F. SP, Ed.) Revista Direito GV, 7(1), Jan.-Jun. 2011, pp. 155-176.

SCHMITT, C. Teoría de La Constitución. (F. Ayala, Trad.) Madrid, Espanha: Alianza Universidad Textos, 1996 [1982]. SHAVELL, S. The Fundamental Divergence Between the Private and the Social Motive to Use the Legal System. Journal of Legal Studies, 1997, XXXVI, pp. 575-516.

SHERWOOD, R. M.; SHEPHERD, G.; SOUZA, C. M. Judicial systems and economic performance. The Quarterly Review of Economics and Finance, 34 (Supplement 1), 1994, pp. 101-116.

SILVA, F. C. Conciliação Cível em Primeira Instância em São Paulo: Perspectiva da Análise Econômica do Direito. (I. T. Junior, Ed.) Economic Analysis of Law Review, 2 (1), 2011, pp. 65-94.

UNITED NATIONS. World Population to 2300. United Nations, Department of Economic and Social Affairs. New York: United Nations, 2004.

WEBER, M. Economia e sociedade: fundamentos da sociologia compreensiva (Vol. 2). (R. Barbosa, \& K. E. Barbosa, Trads.) Brasília, DF, Brasil: Universidade de Brasília, 1999 [1920].

WORLD BANK. World Development Report 2002: Building Institutions for Markets. Washington, DC: Oxford University Press, 2001.

\section{Ivo Teixeira Gico Jr.}

SRTVS, Qd. 701, BI. 0, n. 110, Salas 563-566

Ed. Centro Multiempresarial - 70340-000

Brasília - DF - Brasil gicoladsg.com.br
Professor no Centro Universitário de Brasília (UniCeub) Doutor em DiReito pela Universidade de São Paulo (USP) Doutor em ECONOMIA PELA Universidade de Brasília (UnB) Mestre com Honra Máxima pela Columbia Law School 
